\title{
Economics of milk processing in cooperative sector of Haryana
}

\author{
Ajmer Singh, BS Chandel, AK Chauhan, Jagruti Das and Ravishankara KM
}

Received: 11 February 2021 / Accepted: 25 May 2021/ Published online: 27 July 2021

(C) Indian Dairy Association (India) 2021

\begin{abstract}
In the rural sector, dairying and milk production is an important economic activity and has become a secondary source of income and employment. Cooperatives play an important role in animal husbandry and dairying sector, which contributes about one-fourth of agricultural GDP of the country. This study works out the cost of collection, chilling and transportation to arrive at economics of milk processing and manufacturing of milk products in Haryana by selecting milk plants from different zones in the cooperative sector. The economics of milk processing in Haryana show that procurement cost was found to be higher in Western zone which was estimated to Rs. 1.83 per litre of milk compared to Rs. 1.67 per litre in Eastern zone. Out of which transport cost accounted for maximum share $(54.57 \%)$ followed by transportation cost $(54.57 \%)$, chilling cost $(24 \%)$, collection cost $(17.14 \%)$ and reception cost $(8.57 \%)$. The highest profit was recorded in Dahi making which which yielded a profit over cost of 23.76 percent. The other higher profit giving products were double toned milk and ghee, which yielded profit over cost of 15.21 and 11.88 percent respectively. The profit margin for Paneer was found to be lowest at $7.76 \%$ with cost of Rs 16.05 per $\mathrm{kg}$. The information on the profitability of different products in Haryana can be handy to reorient the product mix and production scale by superimposing the cost of manufacturing and demand of different products over it.
\end{abstract}

DESM Division, ICAR-National Dairy Research Institute, Karnal-132 001, Haryana, India

Ajmer Singh $(\bowtie)$

DESM Division, ICAR-National Dairy Research Institute, Karnal-132 001, Haryana, India

Email: ajmerskundu@gmail.com
Keywords: Cooperatives, Efficiency Economics, Milk processing

JEL Classification: Q10, Q13

\section{Introduction}

The Dairy sector in India has grown substantially over the years. India ranks first among the world's milk producing nations, achieving an annual output of 186.40 million tonnes during the year 2018-19. About 80 million rural households are engaged in milk production with very high proportion of small \& marginal and landless dairy farmers, (DAHD, 2020). In India, about $54 \%$ of the milk is available for sale to organized and unorganized players. Organized sector comprise of Government, Producers' Owned Institutions (Milk Cooperatives \& Producer Companies) and Private players. Cooperatives play an important role in animal husbandry and dairying sector which contributes about onefourth of agricultural GDP of the country (DAHD, 2020; Kumar, 2011). At present 210 Dairy Cooperative Milk Unions exist in the country which covers about 16.54 million farmers $(20 \%$ of dairy farmers) under the ambit of 185,903 village level dairy corporative societies. According to a report by IMARC Group, the Indian dairy industry was worth a value of INR 9,168 Billion in 2018 and to reach a value of INR 21,971 billion by 2024 (IMARC, 2020). Dairy cooperatives are recognised as engine for the development of dairy industry in India because of their economic advantages, democratic character and social purpose. The cooperative sector, which balances the interests of producers and consumers, is best suited for dairy development. They possess inherent potentialities and in-built provisions to serve the cause of rural development.

Promotion of cooperatives is widely viewed as the most important institutional arrangement for spurring dairy development in India. Dairy cooperatives have led to a significant increase in both milk production and productivity, decrease in cost of milk production, reduce transaction costs of accessing inputs, information, technology, and markets and a realization of higher prices and profits (Kumar et al. 2011). Besides, dairy cooperatives have potential for joint development of innovations and sharing among members. In view of importance of dairy cooperative sector in 
the industry this paper attempts to elucidate the performance of milk plants working under the ambit of dairy cooperative system in the state of Haryana.

\section{Materials and Methods}

Two milk plants having the highest milk handling performance from two NARP zones (Ghosh, S.P., 1986) of Haryana state, viz, Ballabhgarh plant from Eastern and Western zone were selected for the study. The milk plants were operating under the management of Haryana Dairy Development Cooperative Federation Ltd. with the brand name Vita. There are six milk unions operating under the federation in the state. The major products manufactured in both the plants include Pasteurized Liquid Milk, Ghee, Skimmed Milk Powder, Paneer, Dahi, Lassi and Kajupinni. The primary data during 2014 to 2015 pertaining to economic aspects from chilling units, Bulk Milk Coolers (BMC), Milk procurement societies and different sections of the milk plant were collected from the records of the plants, by taking the actual observations on temperature and quantity at the time of manufacturing of products and holding the interviews and discussion with the staff working in the plant. The collected data were analysed by using the methodology as follows:

Milk procurement $\cos t=$ Cost of Collection + Cost of transportation + Cost of Chilling + Reception Cost

Cost of collection per litre of milk $=\frac{\text { Total cost of milk collection }}{\text { Total quantity of milk collected }}$

Transportation cost per litre of milk $=\sum_{i=1}^{n} \frac{\mathrm{TCi}}{\mathrm{MTi}}$

Where,

$\mathrm{TC}_{\mathrm{i}}=$ Total transportation cost on the $\mathrm{i}^{\text {th }}$ route,

$\mathrm{MT}_{\mathrm{i}}=$ Total quantity of milk transported on the $\mathrm{i}^{\text {th }}$ route

$\mathrm{n}=$ Number of transport routes

Cost of chilling per litre of milk $=\frac{\text { Total cost of chilling }}{\text { Total quantity of milk chillec }}$
The cost incurred on different components was considered for estimating the cost of products manufactured at the plants.

Steam

Steam requirement $(\mathrm{Kg})=.\frac{\mathrm{MXSXT}}{\mathrm{L}}$

Where,

$\mathrm{M}=$ Quantity of the product to be heated (kg.)

$\mathrm{S}=$ Specific heat of product

$\mathrm{T}=$ Temperature difference $\left(\mathrm{T}_{1}-\mathrm{T}_{2}\right.$, initial and final temperature of the product in centigrade)

$\mathrm{L}=$ Latent heat of steam

Refrigeration load $($ kilo Cal $)=$ M X S X T

Where,

$\mathrm{M}=$ Quantity of product to be cooled $(\mathrm{kg})$

$\mathrm{S}=$ Specific heat of the product

$T=$ Temperature difference in centigrade $\left(T_{1}-T_{2}\right)($ Ahmed, 1997)

\section{Results and Discussion}

For calculation of cost of milk products manufacturing, there is a need to work out the cost of milk procurement and resource utilization in dairy plants.

\section{Procurement cost}

Milk procurement cost which includes cost incurred on collection, transportation and chilling of milk and reception, was estimated and presented in Table 1. The procurement cost was found to be higher in Western zone which was estimated to Rs. 1.83 per litre of milk compared to Rs. 1.77 per litre in Eastern zone. The transportation cost was dominant in both the zones which accounted for 43.72 and 66.47 percent of procurement cost in Western and Eastern zone respectively. The overall cost of milk procurement was found to be Rs. 1.81 per litre in Haryana. The

Table 1 Milk procurement cost of milk plants in Haryana (Rs./litre)

\begin{tabular}{lllll}
\hline Sl. No. & Components & Eastern zone & Western zone & Over all \\
\hline 1 & Collection cost & $0.12(6.77)$ & $0.48(26.23)$ & $0.3(16.57)$ \\
2 & Transportation cost & $1.11(62.72)$ & $0.80(43.72)$ & $0.96(53.03)$ \\
3 & Chilling cost & $0.44(24.87)$ & $0.40(21.86)$ & $0.42(23.21)$ \\
4 & Reception Cost & $0.1(5.65)$ & $0.15(8.20)$ & $0.13(7.19)$ \\
& Procurement cost & $1.77(100)$ & $1.83(100.00)$ & $1.81(100.00)$ \\
\hline
\end{tabular}

Figure in the parentheses are percent to total 
studies done on similar aspects found procurement cost of milk in the similar range (https://www.vitaindia.org.in/milk-plants)

\section{Resource utilization in dairy plants}

Costs of different types of resource used in the plants were calculated and discussed below.

\section{Cost of steam production}

Steam is the root source of energy in the milk plant. The production of steam in the selected plants was 10512 and 5840 metric tonnes in Eastern zone and Western zone plants respectively. Among the components of cost in producing steam, cost on coal was found to be highest in both plants with annual cost of Rs 2360.82 crores $(59.08 \%)$. The other major costs involved in producing steam in both the selected plants were found to be labour and electricity which accounted for 8.89 and 7.93 percent respectively. The fixed cost in the study area was 5.05 percent to total cost or $0.105 \mathrm{Rs} / \mathrm{kg}$ of steam produced in the study area. The cost on depreciation of buildings and machinery was the considered as fixed cost while estimating cost of steam production. The other variable cost components involved in producing steam were water, softening of water and annual maintenance charges. The total variable cost for steam production accounted for 69.35 per cent of the total cost. Chauhan et al. (2015) corroborates the findings with a difference in the cost of steam production in Haryana. The difference found in the cost of steam production may be due to the cheap source of fuel being used in the studied plant. The plant used rice husk as a source of energy in most of the time and furnace oil in some cases as steam produced by rice husk is three times more that of furnace oil.

\section{Cost of refrigeration}

The overall total cost of refrigeration in the study area was Rs. 5808583 per year. The total variable cost contributes about 96 per cent whereas the rest was fixed cost. Among different component of cost, cost for electricity was highest (78 percent) followed by labour (10 per cent) which were the other major costs. Water and annual maintenance charges of refrigeration section shares 1.76 and 0.49 per cent respectively.

\section{Cost of manufacturing of products}

Product wise cost of manufacturing was worked out for the products like standardized milk, full cream milk, toned milk, double toned milk, paneer, ghee, Dahi and depicted in to variable cost which include cost of critical inputs/ resources such as Raw Material, Labour, Electricity, Water, Steam, and Refrigeration in addition to expenditure on Quality Control, Miscellaneous items, Packaging Material and Sundries and fixed cost comprising

Table 2 Component wise manufacturing cost of different products

\begin{tabular}{|c|c|c|c|c|c|c|}
\hline \multirow[t]{2}{*}{ Cost Components } & \multicolumn{2}{|c|}{ Eastern zone } & \multicolumn{2}{|c|}{ Western zone } & \multirow{2}{*}{$\begin{array}{l}\text { Overall } \\
\text { Unit cost } \\
\text { (Rs/L.) }\end{array}$} & \multirow[b]{2}{*}{$\begin{array}{l}\text { Percentage } \\
\text { cost }\end{array}$} \\
\hline & $\begin{array}{l}\text { Unit cost } \\
\text { (Rs/L.) }\end{array}$ & $\begin{array}{l}\text { Percentage } \\
\text { cost }\end{array}$ & $\begin{array}{l}\text { Unit cost } \\
\text { (Rs/L.) }\end{array}$ & $\begin{array}{l}\text { Percentage } \\
\text { cost }\end{array}$ & & \\
\hline \multicolumn{7}{|l|}{ Standardized milk } \\
\hline Total VC & 36.04 & 99.78 & 34.95 & 95.81 & 35.52 & 97.77 \\
\hline Total FC & 0.08 & 0.22 & 1.53 & 4.2 & 0.81 & 2.22 \\
\hline Total & 36.12 & 100 & 36.48 & 100 & 36.30 & 100 \\
\hline \multicolumn{7}{|l|}{ Full Cream Milk } \\
\hline Total VC & 42.06 & 99.71 & 40.72 & 94.45 & 41.42 & 97.04 \\
\hline Total FC & 0.12 & 0.29 & 2.4 & 5.57 & 1.27 & 2.96 \\
\hline Total cost & 42.18 & 100 & 43.12 & 100 & 42.65 & 100 \\
\hline \multicolumn{7}{|c|}{ Double Toned Milk } \\
\hline Total VC & 27.82 & 99.72 & 27.26 & 92.76 & 27.56 & 96.14 \\
\hline Total FC & 0.08 & 0.29 & 2.12 & 7.21 & 1.10 & 3.84 \\
\hline Total cost & 27.9 & 100 & 29.39 & 100 & 28.65 & 100 \\
\hline \multicolumn{7}{|l|}{ Ghee } \\
\hline Total VC & 330.31 & 99.01 & 331.96 & 98.71 & 330.335 & 98.85 \\
\hline Total FC & 3.31 & 0.99 & 4.34 & 1.3 & 3.83 & 1.14 \\
\hline Total cost & 333.62 & 100 & 336.3 & 100 & 334.17 & 100.00 \\
\hline \multicolumn{7}{|l|}{ Paneer } \\
\hline Total VC & 234.77 & 99.77 & 200.84 & 97.94 & 217.795 & 98.91 \\
\hline Total FC & 0.54 & 0.23 & 4.25 & 2.07 & 2.395 & 1.09 \\
\hline $\begin{array}{l}\text { Total cost } \\
\text { Dahi* }\end{array}$ & 235.31 & 100 & 205.09 & 100 & 220.2 & 100 \\
\hline Total VC & 16.03 & 100 & 10.35 & 100 & 13.19 & 100 \\
\hline
\end{tabular}

*. In case of Dahi, fixed cost could not be ascertained due to non-availability of relevant data 
Administration \& Supervision and Interest \& Depreciation (table2).

\section{Standardized milk}

The component wise cost of manufacturing standardized milk was estimated and presented in Table 2. The manufacturing cost of standardized milk in the study area was found to Rs. 36.30 per litre. (Rs. 36.12 and Rs. 36.48 from Eastern zone and Western zone plants respectively). The variable cost alone accounted for more than 99 percent $(99.78 \%$ ) of total cost of manufacturing in Eastern zone where as it accounted to the tune of 95.81 percent in Western zone. The average proportion of variable cost in the study area was found to be 97.77 percent (table 2). The major component of fixed cost was found to be administration and supervision cost which was Rs. 0.08 (0.22\%) and Rs. 1.37 (3.76\%) per litre in the Eastern and Western zone respectively. The other components of fixed cost waswere interest and depreciation.

\section{Full cream milk}

:The variable cost accounted for Rs 42.06 (99.71 percent of total cost) and the fixed cost was merely 0.29 percent of total cost in Eastern zone. In the Western zone, it accounted for Rs 40.72 (94.45 percent of total cost) and the share of fixed cost observed was 5.57 percent. The other major costs observed were, Administration \& Supervision cost, packaging material cost and labour cost which were estimated to be Rs. 1.97 (4.57\%), Rs. 0.67 $(1.55 \%)$ and Rs. $0.53(1.23 \%)$ respectively. The overall manufacturing cost of full cream milk in the study area was estimated to be Rs. 42.65 per litre (97.04 percent) in the study area and the raw material cost was Rs. 39.58 (92.80\%) as shown in Table- 2 .

\section{Double Toned Milk (DTM)}

Total cost of manufacturing DTM was estimated to be Rs. 27.90 per litre in the Eastern zone out of which Rs.26.38 i.e., about 94.55 percent was raw material cost. The average variable cost was Rs. 27.56 per litre (96.14) and the fixed cost was Rs. 1.10 per litre $(3.84 \%)$. The cost of manufacturing was higher in Western zone (Rs 29.39) where as in Eastern zone, it was only Rs 27.90. Overall, it was Rs 27.56 lit.

\section{Ghee}

Ghee was being manufacturing in the study area at Rs 330.34/ lit with hardly any difference over the zones (Rs 330.31 in Eastern zone and Rs 331.96 in Western zone). The variable cost constituted up to 98.80 percent of cost of manufacturing in the study area.

\section{Paneer}

On the other hand, in case of Paneer, cost of manufacturing was differing significantly between the zones. It was Rs $234.77 / \mathrm{kg}$ in Eastern zone and Rs $200.84 / \mathrm{kg}$ in Western zone. Overall, cost of manufacturing Paneer in the study area was found to be Rs 217.79/ $\mathrm{kg}$.

\section{Dahi}

Total variable cost of Dahi was estimated at Rs 13.19 per pack of $200 \mathrm{ml}$ in Eastern zone and Rs 10.35 in Western zone.The cost of manufacturing Dahi could not be bifurcated into variable cost and fixed cost because of unavailability of records on cost aspects with the plants.

\section{Cost of critical inputs/ resources in the manufacturing of products}

The study of usage of critical inputs and their costs in turn form the basis of strategic planning for the milk plants. So, the information was generated and presented product wise in table3.

\section{Standardized milk}

Among the different cost components, cost on raw material (raw milk) was dominant as it accounted for more than 90 percent of total cost on both the selected plants which is Rs. 34.52 (95.57\%) and Rs. 33.16 (90.90 \%) per litre in Eastern and Western zone plants respectively. The overall cost of raw material in manufacturing standardized milk in the study area was Rs. 33.84 per litre which was about 93.22 percent of total cost. The other major costs observed in manufacturing standardized milk was Refrigeration cost $(1.39 \%)$ as depicted in table -3 . The other minor cost components observed were Labour $(0.23 \%)$, Electricity $(0.12 \%)$, Steam $(0.66 \%)$, Water $(0.03 \%)$. The remaining expenditures can be ascertained to Quality Control, Miscellaneous items, Packaging Material and Sundries and fixed cost comprising Administration \& Supervision and Interest \& Depreciation.

\section{Full Cream Milk}

Component wise cost analysis revealed that raw materials alone accounted for 95.87 per cent of total expenditure in the selected plant of Eastern zone and 89.80 percent in Western zone. The overall contribution of critical resources can be presented as Raw material (92.8\%), Labour (0.74\%), Electricity (0.12\%) Water $(0.04 \%)$, Steam $(0.55 \%)$ and Refrigeration (1.18\%). These resources were used more in Western zone.

\section{Double Toned Milk (DTM)}

Overall, the main critical input ie raw materialcosted up to $89.98 \%$ in the manufacture of DTM. It costed more in Eastern zone $(94.55 \%)$ than in Western zone $(85.65 \%)$. The raw material was followed by refrigeration $(1.78 \%)$, steam $(0.84 \%)$ and labour 
$(0.37 \%)$. Other critical inputs were having very less and insignificant contribution (table-3).

\section{Ghee}

It is interesting to note that contribution of raw material ie milk found to be the $97.11 \%$ in Eastern zone and $95.15 \%$ in Western zone (overall, it was $96.36 \%$ ). The zonal variation in this contribution might be because of difference and variation in the prices. In case of ghee, the other important inputs were found to be labour $(0.56 \%)$ and electricity $(0.16 \%)$ as shown in table-3.

\section{Paneer}

The picture of cost of key inputs in paneer manufacturing was no different from that of ghee. Here also, raw material ie milk contributed upto $95.46 \%$ of the cost of manufacturing followed by labour $(1.39 \%)$ and electricity $(0.16 \%)$ being other inputs contributing at very low level.

\section{Dahi}

Table 3 Cost of critical resources/ inputs in manufacture of different products (Rs per Lit/ $\mathrm{kg}$ )

\begin{tabular}{|c|c|c|c|c|c|c|c|}
\hline \multirow[t]{2}{*}{ Sl. No } & \multirow[t]{2}{*}{ Cost Components } & \multicolumn{2}{|c|}{ Eastern zone } & \multicolumn{2}{|c|}{ Western zone } & \multicolumn{2}{|l|}{ Overall } \\
\hline & & $\begin{array}{l}\text { Unit } \\
\text { cost }\end{array}$ & $\begin{array}{l}\text { Percent } \\
\text { cost }\end{array}$ & Unit cost & $\begin{array}{l}\text { Percent } \\
\text { cost }\end{array}$ & $\begin{array}{l}\text { Unit } \\
\text { cost }\end{array}$ & $\begin{array}{l}\text { Percent } \\
\text { cost }\end{array}$ \\
\hline \multicolumn{8}{|c|}{ Standardized milk } \\
\hline 1 & Raw Material & 34.52 & 95.57 & 33.16 & 90.9 & 33.84 & 93.22 \\
\hline 2 & Labour & 0.09 & 0.25 & 0.08 & 0.22 & 0.09 & 0.23 \\
\hline 3 & Electricity & 0.07 & 0.19 & 0.02 & 0.05 & 0.05 & 0.12 \\
\hline 4 & Water & 0.01 & 0.03 & 0.01 & 0.03 & 0.01 & 0.03 \\
\hline 5 & Steam & 0.14 & 0.39 & 0.34 & 0.93 & 0.24 & 0.66 \\
\hline 6 & Refrigeration & 0.61 & 1.69 & 0.4 & 1.1 & 0.51 & 1.39 \\
\hline \multicolumn{8}{|c|}{ Full Cream Milk } \\
\hline 1 & Raw Material & 40.44 & 95.87 & 38.72 & 89.8 & 39.58 & 92.8 \\
\hline 2 & Labour & 0.1 & 0.24 & 0.53 & 1.23 & 0.32 & 0.74 \\
\hline 3 & Electricity & 0.08 & 0.19 & 0.02 & 0.05 & 0.05 & 0.12 \\
\hline 4 & Water & 0.01 & 0.02 & 0.02 & 0.05 & 0.02 & 0.04 \\
\hline 5 & Steam & 0.14 & 0.33 & 0.33 & 0.77 & 0.24 & 0.55 \\
\hline 6 & Refrigeration & 0.61 & 1.45 & 0.4 & 0.93 & 0.51 & 1.18 \\
\hline \multicolumn{8}{|c|}{ Double Toned Milk } \\
\hline 1 & Raw Material & 26.38 & 94.55 & 25.17 & 85.64 & 25.77 & 89.98 \\
\hline 2 & Labour & 0.07 & 0.25 & 0.14 & 0.48 & 0.11 & 0.37 \\
\hline 3 & Electricity & 0.05 & 0.18 & 0.1 & 0.34 & 0.08 & 0.26 \\
\hline 4 & Water & 0.01 & 0.04 & 0.02 & 0.07 & 0.02 & 0.05 \\
\hline 5 & Steam & 0.14 & 0.5 & 0.34 & 1.16 & 0.24 & 0.84 \\
\hline 6 & Refrigeration & 0.61 & 2.19 & 0.41 & 1.4 & 0.51 & 1.78 \\
\hline \multicolumn{8}{|l|}{ Ghee } \\
\hline 1 & Raw Material & 323.99 & 97.11 & 320 & 95.15 & 321.995 & 96.36 \\
\hline 2 & Labour & 1.72 & 0.52 & 2 & 0.59 & 1.86 & 0.56 \\
\hline 3 & Electricity & 0.41 & 0.12 & 0.64 & 0.19 & 0.53 & 0.16 \\
\hline 4 & Water & 0.15 & 0.04 & 0.03 & 0.01 & 0.09 & 0.03 \\
\hline 5 & Steam & 0.48 & 0.14 & 0.85 & 0.25 & 0.67 & 0.20 \\
\hline 6 & Refrigeration & 0 & 0.00 & & 0.00 & 0 & 0.00 \\
\hline \multicolumn{8}{|l|}{ Paneer } \\
\hline 1 & Raw material & 227.78 & 96.8 & 192.64 & 93.93 & 210.21 & 95.46 \\
\hline 2 & Labour & 3.25 & 1.38 & 2.85 & 1.39 & 3.05 & 1.39 \\
\hline 3 & Electricity & 0.12 & 0.05 & 0.58 & 0.28 & 0.35 & 0.16 \\
\hline 4 & Water & 0.21 & 0.09 & 0.02 & 0.01 & 0.11 & 0.05 \\
\hline 5 & Steam & 0.45 & 0.19 & 0.43 & 0.21 & 0.44 & 0.2 \\
\hline 6 & Refrigeration & 0.45 & 0.19 & 0.22 & 0.11 & 0.33 & 0.15 \\
\hline \multicolumn{8}{|l|}{ Dahi } \\
\hline & Raw material & 12.03 & 75.04 & 5.97 & 57.69 & 9.00 & 67.91 \\
\hline & Processing charge & 1.18 & 7.36 & 2.13 & 20.54 & 1.66 & 12.34 \\
\hline
\end{tabular}




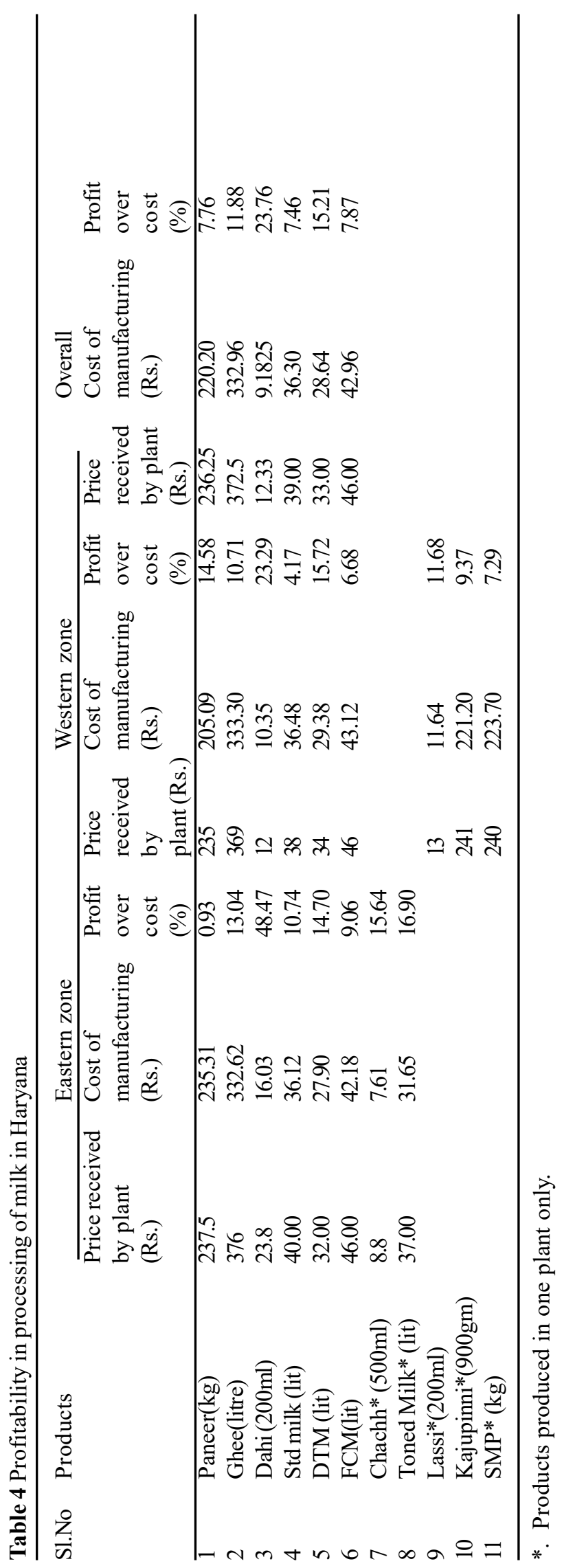

In case of dahi manufacturing, contribution of raw material was found to be $67.91 \%$ which was higher in Eastern zone $(75.84 \%)$ than in Western zone $(57.69 \%)$. The other processing charges (combining all other critical inputs) were $12.34 \%$ being higher in Western zone (20.54\%) than in Eastern zone (7.36\%). It seems that prices might be having a role in this contribution and causing variation between the zones.

\section{Profitability of products}

Profitability of the dairy products manufactured in Eastern zone is presented in Table 4. The information contained in the table reveals that Dahi turned out to be the most profitable product (48.47 per cent) followed by Toned Milk (16.90 per cent), Chach (15.64 per cent), Double Toned Milk (14.70 per cent), Ghee (13.04 per cent), Standardized milk (10.74 per cent) and Full Cream Milk (9.06 per cent). Among different products manufactured, Paneer manufacturing turned out to be the lowest profitable proposition ( 0.93 per cent). There is need to explore the possibility to increase the profits in Paneer manufacturing by increasing the price of the product or to adopt some suitable steps to use the residual whey for by products such as whey based beverages, whey powder and in pharmaceutical industry to bring down the cost.

Profitability of the dairy products manufactured in Sirsa milk plant(western zone) was worked out by comparing the unit cost with the unit price received by the plant for sale of different dairy products. The information contained in the Table 4 revealed that Dahi turned out to be the most profitable product (23\%) followed by Lassi (19\%), Toned Milk (24.76\%), and KajuPinni (17.55\%). The Paneer have the least profit over margin of 2 percent. The product wise profitability in processing milk in the study area was worked out and presented in Table 4. Comparatively higher profit over cost was found in processing milk to Dahi which yielded a profit over cost of 23.76 percent which was highest among the products. The other higher profit giving products were double toned milk and ghee which yielded profit over cost of 15.21 and 11.88 percent respectively. However higher profit margin was seen in case of ghee which was Rs. 39.54 per unit which was due to higher price of the product i.e., Rs. 372.5 Rs./ litre ghee. The profit margin for Paneer was found to be Rs. 16.05 per $\mathrm{kg}$ of Paneer. The profit margin for Dahi, Standardized Milk, Full Cream Milk and Double Toned Milk was found to be Rs. 3.14 , Rs. 2.70 , Rs. 4.36 and Rs. 3.35 per litre respectively.

\section{Conclusions}

The economics of milk processing in Haryana show that procurement cost was found to be higher in Western zone, estimated at Rs. 1.83 per litre of milk as compared to Rs. 1.67 per litre in Eastern zone. Out of the total procurement cost, transport cost formed of a major part $(54.57 \%)$. Cost of manufacturing of different products was found to be lower in Eastern zone of the state except Paneer and Dahi where the case was reverse. The 
major chunk of cost of manufacturing was taken by the variable cost and the fixed cost contributed up to $1.14 \%$ to $3.84 \%$ of the total cost. The contribution of critical inputs to the manufacturing cost show that major portion ( upto $89.98 \%$ to $93.22 \%$ ) goes to the raw materials in manufacturing of these products followed by refrigeration ( 0.00 to $1.39 \%)$, steam ( 0.2 to $0.84 \%$, labour $(0.23$ to $1.39 \%$ ) and water ( 0.03 to $0.05 \%)$. In case of Ghee and Paneer, Labour was found second most important component of cost of manufacturing after Raw materials.

The profitability of different products analysed show that comparatively higher profit over cost was found in processing milk to Dahi which yielded a profit over cost of 23.76 percent. The other higher profit giving products were Double Toned Milk and Ghee which yielded profit over cost of 15.21 and 11.88 percent respectively. The profit margin for Paneer was found to be lowest at $7.76 \%$ with cost of Rs 16.05 per kg. So, Dahi and its different variants and Double Toned Milk can be produced to increase the profits from these plants. While coming to the operating cost scenario, proper technology and management in terms of the electricity and refrigeration cost is important to ensure higher profitability of the cooperative milk processing plants. The study showed that all the products manufactured in the milk plants are generating profits. The information on the profitability of different products in Haryana can be a useful tool for the Management to reshuffle the product mix of the plants on the basis of cost of manufacturing, profits and demand of different products.

\section{Acknowledgement}

The paper is based on IRC project G-47. The authors profoundly thank the Director NDRI, Karnal for sanctioning the project and all the financial and logistic help provided. We also thank the reviewer and anonymous referee for comments and valuable suggestions.

\section{References}

Ahmed, T (1997) Dairy Plant Engineering and Management, IVth Edition, Allahabad:Kitab Mahal, 22-A, Sarojini Naidu Marg, pp 48-51

Alli M, Chauhan, AK, Franco D, Singh S (2015) Economics of Resource Utilization for manufacturing of dairy products in a cooperative dairy plant in coastal Odisha. Indian J Econ Dev16:631-635

DAHD. 2020. Annual Report 2018-19. Dairy Development, pp 69-72

Kumar A, Staal SJ, Singh DK (2011) Smallholder dairy farmers' access to modern milk marketing chains in India. Agric Econ Res Rev 24: 243-253

IMARC (2020) The International Market Analysis Research and Consulting Group, retrieved from https://www.imarcgroup.com/indian-dairyindustry-cross- 18599

Haryana Dairy Development Cooperative Federation Ltd (HDDCFL), retrieved from https://www.vitaindia.org.in/milk-plants

Mane SR (2013) Energy Management in a Dairy Industry. Proceedings of Institute of Research and Journals, International Conference, International Standard Book Number: 978-93-82702-25-2.

Modi A, Prajapat R (2014) Pasteurization process energy optimization for a milk dairy plant by energy audit approach. Int J Sci Technol. Res 3:181-188

Rangaswamy N, Dhaka JP (2007) Constraints faced by Co-operative and Private dairy plants in Tamil Nadu - A comparative analysis. Indian J Dairy Sci 60:300-306

TherajaBL,Theraja AK (1992) A Text Book of Electrical Technology, New Delhi: S. Chand and CompanyLtd.,pp-46 